九州大学学術情報リポジトリ

Kyushu University Institutional Repository

\title{
The Ideological Underpinnings of Private Trade in East Asia, ca. 800-1127
}

SATTLER, GREGORY

University of California, Los Angeles: PhD Student, Department of History

https://doi.org/10.5109/4377706

出版情報: Journal of Asian Humanities at Kyushu University. 6, pp.41-60, 2021-03. Kyushu University, School of Letters, Graduate School of Humanities, Faculty of Humanities バージョン:

権利関係 : 


\title{
The Ideological Underpinnings of Private Trade in East Asia, ca. 800-1127
}

\author{
GREGORY SATTLER
}

\section{Introduction}

$\mathbf{T}$

HE image of the merchant, both from our presentday conceptions and as depicted in some of the writings of premodern East Asian scholars, may require some reinterpretation. In particular, the idea of an irreconcilable divide between the social positions of the merchant and the official has dominated discourse on the economic, trade, social, and intellectual history of this region to the point that the separation of these two roles is often seen as a fundamental characteristic of traditional Chinese - and by extension East Asian culture. In this dichotomy, the merchant is usually depicted in a negative light: as greedy, petty, or of less importance to the overall functionality of society. This view, as historian Denis Twitchett has pointed out, was promoted by the writers of China's official histories, who gave the misleading impression that the merchant "played no active role in politics or government, and appears in the histories only as the passive object of official policy, or as an offender against the authority of the State."' Such a statement was made in regard to

This essay has benefited from the advice of Ellen Van Goethem Ashton Lazarus, Joseph P. McDermott, Richard von Glahn, and Beverly Bossler. I am grateful for their thoughtful comments and suggestions. merchants of the Tang 唐 dynasty (618-907), though in fact we may find similar points of view in the official histories of earlier and later Chinese dynasties as well. More recently, scholars have come to suspect that officials throughout East Asia were involved in commerce to a much greater extent than most court documents suggest, and a growing body of evidence is highlighting a closer interplay between merchants and officials than was previously believed. Nevertheless, in our attempts to reconstruct the conditions of the past, a common conception persists that the place of the merchant was one that gradually realized a favorable progression over time, or that merchants were by and large a disenfranchised group kept under the thumb of a dominant scholar-bureaucracy.

The disapproving depiction of the merchant is often regarded as originating in antiquity (generally considered as the earliest periods of Chinese history until the consolidation of the Qin 秦 empire in 221 $\mathrm{BCE}$ ), though it has been reinforced by the prioritization

1 Twitchett, "Merchants, Trade and Government in Late T'ang," p. 64. Joseph McDermott has pointed out that this view was reinforced and promoted by Max Weber in The Religion of China: Confucianism and Taoism, which in turn significantly influenced Western perceptions. See McDermott, "Merchants in Late Imperial China: Obstacles and Solutions." 
of the study of Chinese laws in the decades following the Second World War. Yet as research has advanced in recent years, we have come to learn that these laws were not always adhered to or enforced, and that they did not necessarily reflect the views of the majority of any given society, or even of the scholar-officials themselves. ${ }^{2}$

Social distinctions between merchant and official have also led scholars to regard diplomatic trade and private trade as entirely separate concepts, even though interstate exchange was not always so clearly defined in the extant sources. This view is evident in historian John K. Fairbank's assessment that "foreign trade" (private trade) was subordinate to tribute: "No doubt, this quixotic doctrine reflected the anti-commercial nature of the Confucian state, where the merchant was low in the social scale and nominally beneath both the farmer and the bureaucrat, who lived off the produce of the land." ${ }^{3}$ Indeed, it was the case that the merchant ranked the lowest of the four occupational groups ( si min 四民, the other three being officials, farmers, and craftsmen), yet as this system belonged to the idealized perception of antiquity, it could also be seen as a legitimation of the merchant's position. Even in some of the most challenging times, merchants were generally accepted by officials as a necessary evil, if not as an integral institution of the Sage Kings. ${ }^{4}$ And as for the value of tributary exchange over private trade, this is clearly a matter that needs to be considered in the context of time and space-even more so as we contemplate the past views of the inhabitants of polities located near the borders of Chinese states.

As we shall see, the relationship between commerce and what we now regard as Confucian thought was not always one of diametrical opposition. Whether

2 Given the importance of such laws and their availability in various sources, the early emphasis on legal history as a means to conceptualize social circumstances is quite understandable. For laws directed at merchants and commercial activity, see Twitchett, "A Confucian's View of the Taxation of Commerce"; Twitchett, "Merchants, Trade and Government in Late T'ang"; and Twitchett, "The T'ang Market System." For the view that earlier historians overestimated the degree of suppression that the Tang state exerted on merchants, see Twitchett, "The T'ang Market System," p. 241.

3 Fairbank, Trade and Diplomacy on the China Coast, p. 33.

4 Twitchett, "A Confucian's View of the Taxation of Commerce," p. 438. The Sage Kings were mythical sovereigns who were said to rule over China prior to the advent of writing. through tribute, private and semi-private trade, ${ }^{5}$ or the bestowal of gifts on a personal basis, the philosophies on exchange were varied and depended primarily on the dynamics in place between each party involved. And of those who provide the greatest degree of insight on the merchant-official dynamic, we are perhaps best served by observing the maritime traders who sailed between the various states across East Asia. Due to the prestige goods and high-value commodities that they carried, these merchants frequently interacted with notable historical figures, and thus had information about themselves preserved in journals, records, and official histories. We may draw a considerable amount of information from the interactions and activities of these individuals during the span of the ninth to the early twelfth century, most notably in how commerce and its participants therein were regarded in the societies that they traveled to. In particular, a look at their activities may provide ample evidence for a reassessment of the "Confucian" philosophies on commerce, the distinct separation between private and tributary trade, and the place of the merchant in East Asian societies. Yet before we begin to examine these individuals, I will provide a general overview of the traditional conceptions of merchants in Chinese society, so as to establish a basis for understanding how they were perceived in their respective times and places.

\section{The Place of the Merchant in Chinese Society: From Early Conceptions to the Fall of the Northern Song}

In order to understand how merchants were regarded throughout East Asia from the ninth to the twelfth century, we must first consider how they were treated in the Chinese sources both prior to and during this time in question. This is necessary for two reasons. First, the traditional conceptions of merchants, at least among the scholar-officials who wrote about them,

5 Semi-private trade should be considered as trade between private merchants and state representatives, which was common throughout East Asia from the ninth to the twelfth century. In this essay I will refer to both private trade and semi-private trade simply as "private trade" to emphasize the involvement of non-state actors, and to distinguish this form of commercial activity from the exchange of goods between state representatives. Unless otherwise noted, all references to private traders will indicate merchants who were not engaged in trade on behalf of a state. 
were established mainly from the Warring States (Zhanguo 戰國) period (475-221 BCE) to the end of the Later Han (Hou Han 後漢) dynasty (25-220). Second, these perspectives spread to various East Asian polities along with literacy and Chinese texts, and endured over the span of many centuries. ${ }^{6}$ By the time an interstate system of private trade was established across East Asia in the early ninth century, the basis for how government officials were to conceptualize merchants was already rooted in their education.

The most common misconception regarding the merchant in early Chinese history is that from Chinese antiquity onward, agriculture was prized first and foremost among state planners and thus the place of the merchant was unnecessary or of secondary importance. In fact, however, Roel Sterckx has shown that there is only one extant Warring States text that contains a sustained ideological stance in favor of the suppression of merchants, which is the Legalist text Shang jun shu 商君書 (Book of Lord Shang, completed ca. third century BCE). In addition, Sterckx points out that some of the greatest intellectuals of the day, Mencius 孟子 (372-289 BCE) and Xunzi 荀子 (310-235 BCE) among them, actually held favorable views toward the creation of wealth by means other than agriculture. ${ }^{7}$ Song Xi (also Sung Shee) has likewise noted that the suppression of merchants was never a traditional Confucian position, but one which originated from scholars such as Shang Yang 商鞅 (390-338 BCE) who belonged to what is now called the Legalist school of thought. ${ }^{8}$

It was during the centuries that followed the unification of China in 221 BCE that we begin to see the sustained antagonistic rhetoric toward merchants that was later recycled throughout Chinese history. For example, this language is frequently employed in the "Food and Money" chapter of the Han shu 漢書 (Book of Han, compiled 111), ${ }^{9}$ usually in sections that discuss the government's confiscation of the wealth of merchants and the landed elite. At the heart of the

6 For the spread of literacy in East Asia, see Kornicki, Languages, Scripts, and Chinese Texts in East Asia.

7 Sterckx, "Ideologies of the Peasant and Merchant in Warring States China." See also von Glahn, The Economic History of China: From Antiquity to the Nineteenth Century, pp. 75-81, for a detailed discussion on attitudes toward merchants at this time. We see here that Mencius was also critical of the profit motive of merchants.

8 Song, Song shi yanjiu luncong, p. 1.

9 Swann, Food and Money in Ancient China. issue was a concern that merchants were engaging in grain speculation and hoarding, a practice that had a devastating effect on towns and cities in desperate times. Yet it is abundantly clear in this chapter that civil bureaucrats felt their authority was also under threat by the wealth of merchants, who were much harder to tax than farmers and able to exert influence on both local society and state government. ${ }^{10}$ To offset their influence and ability to conceal assets, merchants were at various times restricted from holding office, charged higher rates of tax than farmers, and policies and statements were put forward that promoted agriculture over trade in a style that harkened back to the writings of Shang Yang. Underlying this rhetoric was the model from antiquity in which merchants were listed last among the four categories of professions. By the Former Han (Qian Han 前漢) dynasty (202 BCE-9 CE), this model was being used to emphasize that rather than having a legitimate place as one of the four accepted roles of society, merchants were inferior among the free population.

Yet the views of the compilers of the Han shu were in no way a reflection of a consensus among the scholar-officials of their time. An alternate perspective may be seen in the writings of the historian Sima Qian 司馬遷 (145-86 BCE), who gave a generally favorable depiction of merchants and commerce in the biographies section of the Shi ji 史記 (Records of the Grand Historian, compiled $94 \mathrm{BCE}$ ), and even situated the circulation of goods and the setting of prices into a Daoist worldview. ${ }^{11}$ The place of the merchant was also subject to change based on the policies of each emperor and his administration. There were laws that put the names of merchants on special registers and banned them and their descendants from holding office, wearing silk, riding horses, or owning land, but just as during later dynasties, these laws often went unheeded. ${ }^{12}$ Indeed, many of the wealthy

10 For several of many such examples found throughout the chapter, see ibid., pp. $165,282,311,418$. For a discussion on the topic, see pp. $24-25$

11 Ibid., p. 421. For an excellent analysis of Sima Qian's philosophical discourse on moneymaking in the Shiji, see Nylan, "Assets Accumulating: Sima Qian's Perspective on Moneymaking, Virtue, and History." Of particular interest is Sima Qian's description of successful moneymakers as "uncrowned nobles" (sufeng 素封), discussed on pp. 135-36, 147, 155-58.

12 Lewis, The Early Chinese Empires, p. 76. For remarkably similar circumstances during the Song 宋 dynasty (960-1279), see Shiba, "Sung Foreign Trade," p. 96. At times, prohibitions against 
merchants who engaged in the long-distance trade of luxuries were able to evade them outright. ${ }^{13}$ Even during periods when merchants were subject to some of the harshest limitations, such as during the reign of Emperor Wu of Han (Han Wudi 漢武帝, 151-87 BCE, r. 141-87 BCE), they were nevertheless directly employed in significant government positions, such as heading the state monopolies on salt and iron. ${ }^{14}$ One son of a merchant, Sang Hongyang 桑弘羊 (152-80 BCE), even became vice chancellor (yushi dafu 御史 大夫, also known as "imperial secretary"). ${ }^{15}$ At other times, wealthy merchants could easily give up their tradesman's status to become landlords and still deal in grain and silk, which were considered forms of money alongside coins. ${ }^{16}$ Yet perhaps most indicative of the cultural overlay that exceeded these social distinctions was a widespread attraction to the image of a cultivated intellectual. For at the peak of the popularity of Confucian learning during the Former Han dynasty, even magnates and merchants began to model themselves after Confucian scholars. ${ }^{17}$

In the centuries that followed the collapse of the Han empire in 220, various small, and often volatile, states emerged in its place. In the northern portion of the former empire, trade resumed and even flourished during relatively brief periods of stability. From surviving accounts, we know that ranking officials at this time were well aware of the opportunities inherent in commerce, and were not averse to using their positions as a means of enriching themselves - either through their own businesses or through the coercion of other traders. ${ }^{18}$ In the southern states, the dynamic of merchant

merchants holding office were also relaxed, such as during the reign of Emperor Jing of Han (Han Jingdi 漢景帝, 188-141 BCE, r. 157-141 BCE). See von Glahn, The Economic History of China, p. 108

13 Lewis, The Early Chinese Empires, p. 76.

14 Von Glahn, The Economic History of China, pp. 114-15. For a view that emphasized lower-level bureaucrats engaged in commerce, see Zhu, "Song dai shangren de shehui diwei ji qi lishi zuoyong," p. 129. The periodic administration of salt monopolies by merchants is a recurring theme throughout Chinese history, and we can see that such a practice was alive and well even in the early seventeenth century. See McDermott, "Merchants and Trade Networks in Late Imperial China."

15 Yang, "Government Control of Urban Merchant in Traditional China," p. 188.

16 Ibid., p. 188; Lewis, The Early Chinese Empires, pp. 69-70.

17 Ch'en, "Confucian, Legalist, and Taoist Thought in Later Han," p. 769.

18 Xiong, "The Northern Economy," pp. 321-22. and official appears even more muddled, as certain civil officials and military officers were granted privileges that exempted them from paying commercial taxes. Involvement in commerce by officials was also common in these states, to the point that merchants would attach themselves to officials as "disciples" so as to evade taxes. Officials were even dispatched at the personal behest of imperial family members to trade with foreigners at domestic port cities. It was also not uncommon for officials of this period to be of a merchant background, which may be an indication that mercantile families enjoyed a more favorable social status compared to previous times. ${ }^{19}$

Denis Twitchett has contributed much to our knowledge of merchants during the Tang dynasty. Thanks to his efforts, we know that edicts were issued in this period which set into law the model of the four professions, forbade merchants and craftsmen from associating with officials, and denied merchants access to government offices. ${ }^{20}$ But we can also see more clearly at this time that officials sympathetic to Confucian views tended to be less hostile toward merchants than some of their more heavy-handed utilitarian counterparts. Some scholar-officials such as Bo Juyi 白居易 (772-846) even argued that merchants or their progeny should be allowed to take the imperial examinations, a position that was based on long-held principles that officials should be employed on the grounds of ability rather than heredity. ${ }^{21}$ Other officials were able to block attempts to increase the taxation of commerce in part because such measures could lead to social unrest..$^{22}$

It would seem that toward the end of the Tang dynasty, decreased regulation brought about by the decentralization of authority led to an unprecedented improvement of the merchant's lot in society. Indeed, their economic prospects were surely advanced in such

19 Liu, "The Southern Economy," pp. 346-48.

20 Twitchett, "Merchants, Trade and Government," pp. 64-68. Similar restrictions were also in place in Japan by the eighth century, as to a greater extent, its laws were copied directly from Tang legal codes. However, one interesting exception is that Japanese legislators chose not to adopt Tang laws that prohibited the involvement of officials in commerce. In addition, the Yōrō 養老 Code (implemented in 757) did not contain a provision delineating the four professions, which is thought to have existed in previous Japanese codes. See Farris, "Trade, Money, and Merchants in Nara Japan."

21 Twitchett, "Merchants, Trade and Government," pp. 90-92.

22 Twitchett, "A Confucian's View," p. 444. 
an environment. As Twitchett states, "One of the most striking developments during the T'ang period is the gradual improvement of the position of merchants and artisans, traditionally held in low esteem, and the parallel change in the attitude of government and the ruling elite towards them." ${ }^{23}$ Yet I am curious as to how profound these changes were, and whether or not a greater variety of extant textual sources from the Tang period onward more acutely highlights a disparity between rhetoric and practical circumstances that we know existed in earlier times as well. Merchants were able to operate with little impediment at certain times during the Han dynasty and prior to the Qin consolidation of imperial China. Societies throughout the Chinese ecumene also underwent a great deal of change following the collapse of the Han dynasty, which at times also resulted in a favorable environment to establish a livelihood in trade. It therefore may be best for us to conceive of an ebb and flow of the social position of merchants throughout Chinese history, rather than of turning points that suggest a permanent transition away from past social conventions.

With this in mind, we may note that contention between officials and merchants was not to end in the mid-eighth century, but actually became more pronounced during the Song 宋 (960-1279) dynasty, particularly in the decades leading up to the Jurchen conquest of the northern half of the state in the early twelfth century. Despite the unique challenges that administrators faced at this time, we see a reuse of rhetoric that intentionally drew parallels to the abusive practices of monopolistic hoarding and speculation during the Han dynasty. This became most evident when the statesman Wang Anshi 王安石 (1021-1086) put forward his New Policies (xinfa 新法) as an ambitious means to mandate changes across all levels of Song society. ${ }^{24}$ In particular, Wang Anshi and his successors were intent on having the government supplant the place of money lenders, and take control of the trade of tea, salt, medicine, and other commodities. In addition, many of the richest households were highly taxed, and the government minted coins at a higher rate than at any time prior to the eighteenth century.

\footnotetext{
23 Ibid., p. 429.

24 See Smith, "Shen-tsung's Reign and the New Policies of Wang An-shih"; Levine, "Che-tsung's Reign (1085-1100) and the Age of Faction"; and Levine, "The Reigns of Hui-tsung (1100-1126) and Ch'in-tsung (1126-1127) and the Fall of the Northern Sung."
}

Part of the means to win support for these changes was to highlight a crisis caused by merchants, who were termed "engrossers." 25

But of course, in practice it was not so simple as to depict the merchant as a threat to society and suppress him or her accordingly. Just as "worthy merchants" had been chosen to head state monopolies during the reign of Emperor Wu of Han, Wang Anshi was criticized by his opponents for employing merchants on a grand scale to help implement his policies as well. ${ }^{26}$ Indeed, the Song government had already established Maritime Trade Superintendency (Shibosi 市舶司) offices by the late tenth century, which subjected long-distance traders to both increased regulation and state support. This brought court-appointed officials and merchants into regular contact and highly formalized relationships, though it also facilitated associations of a more dubious nature. ${ }^{27}$ In fact, many scholars have singled out the Song period as a golden age for merchants, despite the fact that they were more effectively taxed than in previous dynasties. ${ }^{28}$ Such an attribution is based primarily on the economic opportunities that resulted from the Song state's support of commerce throughout the period. But it may be necessary to keep in mind that as with any other period of history, the Song dynasty was a time in which great changes often reversed the fortunes of many in the general population. In other words, a merchant adversely affected by a government monopoly in the time of Wang Anshi would have likely had a different view of his or her economic prospects than one selling essential commodities near Hangzhou Bay (Hangzhou Wan 杭州灣) following the southward relocation of the Song capital in the twelfth century.

As for the question of social mobility in this period, the answers are less clear. At certain times during the

\footnotetext{
25 Smith, "Shen-tsung's Reign," pp. 390-91, 404-405. For positive views on Northern Song monetary policies, see McDermott and Shiba, "Economic Change in China, 960-1279," pp. 377-79; and Liu, "Wrestling for Power," pp. 27-80. See also von Glahn, Fountain of Fortune, pp. 48-50.

26 Smith, "Shen-tsung's Reign," pp. 391, 405.

27 For a discussion of these offices, see Nakamura, "The Maritime East Asian Network in the Song-Yuan Period"; So, Prosperity, Region, and Institutions in Maritime China, pp. 42-49; Schottenhammer, "China's Emergence as a Maritime Power," pp. 460-79; and von Glahn, "The Ningbo-Hakata Merchant Network."

28 In addition to the special taxes and levies directed at merchants at this time, this statement may be applied to the general public as well, as scholars believe that Song societies witnessed some of the highest rates of taxation in Chinese history. See Hartman, "Sung Government and Politics," pp. 23-24.
} 
Song dynasty, such as in the decades following its consolidation in 979, strict regulations were put forward that forbade officials from engaging in commerce and merchants from entering the bureaucracy. But although the children of merchants were not permitted to take imperial examinations, it appears that they were able to flout such rules at certain times. ${ }^{29}$ Furthermore, loopholes dating back to the Han dynasty remained in place that allowed the most successful merchant families to change their status to that of landlords, and then to officials. ${ }^{30}$ Thus we continue to find ample evidence of families with the means to turn wealth into power, though a stark contrast is recognizable between the merchant who amassed great sums of wealth through long-distance trade and the peddler on the street.

Much of the above information would have been known to scholar-officials across East Asia from the ninth to the twelfth century based on their knowledge of historical works and the political circumstances of their times. The same may perhaps also be said for the literate, well-connected, and economically formidable merchants who were among the maritime traders that sailed between states to trade in luxuries and resources. It is in this context that we may begin to consider the ideological basis for which trade-as well as those who engaged in or patronized it - would have been perceived throughout East Asia in the centuries that followed the decline of Tang state authority.

\section{Private Trade and Diplomacy}

The ideals of what we now call Confucianism, including those of the masters of ritual who were referred to as $r u$ 儒, were never intended to be restricted to a single Chinese state, but to be used across the world that existed under heaven (tianxia 天下)-preferably under the rule of a Chinese emperor. For this reason, the spread of Chinese concepts of civilization was promoted by

\footnotetext{
29 Zhu, "Song dai shangren," pp. 133-34. It seems that allowing mer chant or artisan families to participate in the examinations had become such an enduring practice by the middle of the eleventh century that efforts by reformist officials to exclude such families largely ended in failure. Ouyang Xiu 歐陽修 (1007-1072) himself made the argument that keeping the literati a discrete social group was not as important as promoting learning to determine the social worth of an individual. See Bol, "This Culture of Ours," p. 175.

30 Song, Song shi yanjiu luncong, pp. 15-20.
}

successive generations of scholar-officials, and many of the intellectual traditions that were passed on from the Warring States and earlier times formed the basis of the structure in which the representatives of various states were to interact with each other. ${ }^{31}$ Chinese systems of thought were particularly prevalent across East Asia from the fourth to seventh centuries, as Chinese culture gained rapid acceptance within governments on or near the Korean Peninsula before spreading to the Japanese archipelago. In the courts of these states, Confucian values largely influenced the orthodox way in which government was to be conducted, especially in situations that necessitated interaction with representatives of neighboring polities. The scholarofficials of such states, although fully aware of the cultural differences that existed between them and their diplomatic counterparts, found common ground in the education that they received, which was based largely on the same classical texts.

This diplomatic protocol came from what some might term "Confucian" ritual, in that there was a hierarchy of those who participated in the tributary system, and relationships between the rulers of states were often characterized by familial bonds, either through actual intermarriage or as rhetorical devices. But despite the emphasis on ritual and moral conduct, even from the inception of the tributary system, the incentive for states or tribes to participate was most commonly to obtain rare goods and precious commodities through trade. ${ }^{32}$ Such was the means employed by the Chinese state to attract foreign dignitaries from far and wide, on the one hand allowing the emperor or monarch to benefit from the prestige of attracting peoples from distant lands, and on the other hand allowing Chinese governments to influence and be informed on matters outside of their borders. But that is not to say that the favorable trade terms that China bestowed on tributaries were intended only to avail its guests. In actuality, many Chinese rulers and their retinues were eager to receive rare and exotic goods from distant lands as well. ${ }^{33}$ Though tributary trade was from an early time supplemented

31 For interstate diplomacy prior to China's first imperial dynasties, see Lewis, "Warring States," and Fairbank, Trade and Diplomacy, p. 25.

32 Yü, "Han Foreign Relations," p. 416.

33 Schafer, The Golden Peaches of Samarkand, and Hansen, The Silk Road, p. 15. For Chinese and Japanese diplomacy from the Han to Tang dynasties, see Wang, Ambassadors from the Islands of Immortals. 
or superseded by a vibrant system of private trade for many of the Central, West, and South Asian countries and tribes in contact with China, in East Asia the primary means of exchanging goods until the ninth century was through systems of tributary diplomacy. We can see this also remained the case when states in the region engaged in diplomacy that did not involve China, such as the tributary relationship between Japan and Parhae 渤海 (698-926, located in present-day North Korea and Manchuria), which was conducted in a tributary framework, though almost entirely for the purpose of trade. ${ }^{34}$

Much scholarly work has been carried out on the tributary system that characterized diplomacy in East Asia from China's early and mid-imperial periods (approximately third century BCE to thirteenth century $\mathrm{CE}$ ). However, relatively little research has been conducted on the transition from tributary exchange to private trade that occurred in East Asia during this time span. ${ }^{35}$ For although tributary diplomacy - and the exchange of goods therein - can be said to have existed for over a millennium, by the ninth century, a trend was underway in which private trade became the most common means for goods to move across state borders. It was especially the case in states such as Unified Silla (T'ongil Silla 統一新羅, 668-935) and Japan that this new system proved to be a cost-effective means of engaging in commerce, one which did not necessitate the tremendous amount of resources required to send out large tributary ships packed with hundreds of envoys and sailors.

Yet there is much to show that the earliest system of private trade in East Asia was modeled on the system of tributary diplomacy. For instance, many of the characteristics exhibited by the Chinese and Korean merchants who came to Japan from the early ninth century onward drew close similarities with the diplomats who arrived on the archipelago during and prior to that

34 Von Verschuer, Across the Perilous Sea, pp. 20-21. It should nevertheless be pointed out that the initial diplomatic exchanges between Parhae and Japan in the early eighth century seem to have been prompted by the desire of Parhae leaders to form a military alliance. See Wang, Tang China in Multi-Polar Asia: A History of Diplomacy and War, p. 93.

35 For tributary diplomacy, see Wang, Ambassadors from the Islands of Immortals; Yü, "Han Foreign Relations"; Hansen, The Silk Road; and Schafer, The Golden Peaches of Samarkand. For diplomacy conducted on an equal footing during the eleventh century, see Tackett, The Origins of the Chinese Nation; and Rossabi, China Among Equals. time. The earliest indicator of this would be that the first private traders to arrive in Japan were nevertheless recorded in Japanese sources as bearing tribute, a term and practice which frequently appears alongside the activities of merchants in Japanese records in the following centuries. In particular, these traders, who for the first half of the ninth century were largely (but not exclusively) ethnic Koreans, arrived in Japan with the tribute of exotic animals. ${ }^{36}$ This is a practice worthy of our attention as it can be traced back to Han-dynasty diplomatic customs in which representatives from distant states would bring strange creatures as gifts to the Chinese court. ${ }^{37}$ For the most part, in the several centuries that followed the beginning of private trade in Japan, gifts of exotic animals tended to be given to the Japanese court by merchants making their first journey to the archipelago. This is reflected not only in that the names of these merchants often first appear in entries detailing a gift of one or several such animals to the court, but also in that during times of great disruption, such as following the collapse of the Tang dynasty in 907, a wave of merchants bearing gifts of animals can be seen in Japanese sources. ${ }^{38}$

Another function of private traders that closely resembled that of their diplomatic predecessors was the handling of correspondence to and from state courts. This was commonly arranged when court officials wished to contact Buddhist monks and institutions located outside of their borders, though it also occurred when states wished to open direct channels of communication with each other. A notable example of the former situation was in 893 when the Chinese merchant Wang Ne 王訥 (d.u.) carried a letter from a Japanese monk visiting China to the Japanese court, warning that the Tang government was teetering on the edge of annihilation. This information was used by

36 Nihon kiryaku, entries dated Kōnin 弘仁 9 (818).1.13 and Kōnin 11.5 .4 .

37 Schafer, The Golden Peaches of Samarkand, pp. 58-104. As can be seen in this book, this was a common practice during the Tang dynasty as well. For gift-giving in East Asia, see Hyun, "Gift Exchange among States in East Asia During the Eleventh Century."

38 We can see this in the early part of China's Five Dynasties period, for instance in Fusō ryakki, entry dated Engi 延喜 3 (903).11.20; Nihon kiryaku, entry dated Engi 9 (909).11.27; Fusō ryakki, entry dated Engi 19 (919).7.16; Nihon kiryaku, entry dated Shōhei 承平 5 (935).9; and Honchō seiki, entry dated Tengyō 天慶 1 (938).8.23. For an instance during the Song dynasty, see Nihon kiryaku, entry dated Chōwa 長和 4 (1015).2.12. 
the renowned scholar-official Sugawara no Michizane 菅原道真 (845-903) to cancel what would have been Japan's last diplomatic mission to China for centuries to come. ${ }^{39}$ As for the sea merchants' handling of state-tostate correspondence, this frequently occurred between the Five Dynasties (Wudai 五代, 907-979) kingdom of Wu-Yue 吳越 (907-978, located in the present-day Zhejiang area) and the Japanese court from 935 to 953, and also between the Song and Japanese courts toward the end of the eleventh century..$^{40}$

And finally, one of the signature elements of diplomacy between East Asian states was the composition of poetry. Aside, of course, from surviving the often-deadly voyage across the seas, this was one of the most skill-demanding processes that transpired on a tributary mission. In such a setting, leading officials representing their countries exchanged poems in a competitive but genial manner that was nevertheless arranged as a ceremonial event. ${ }^{41}$ Records of the ninth and tenth centuries demonstrate that this process also continued throughout the transition to private trade. Extant pieces of poetry, which include compositions both written by and for the benefit of continental merchants, provide details of their activities that are seldom found in state chronicles. For instance, throughout a waiting period that might last half a year or more, practically nothing was ever recorded regarding the activities of Chinese or Korean merchants during their stay in Japan. One exception, however, would be when a merchant composed poetry for a Japanese audience, an activity that was unequivocally prized by courtiers in the Heian 平安 period (794-1185). The earliest recorded example of this would be in 838 , when the merchant Shen Daogu 沈道古 (d.u.) and his crew stayed at the Kōrokan 鴻臚館, a lodging facility in northern Kyushu originally provided for foreign diplomats and Buddhist

39 Kanke bunsō, vol. 9-10; Borgen, Sugawara, pp. 240-43. It should be noted that in many ways Buddhist monks also held the same responsibilities as sea merchants in assuming the roles of messengers and informants that were formerly held by diplomatic envoys.

40 For the state correspondence between Wu-Yue and Japan, see Worthy, "Diplomacy for Survival," pp. 35-36. For examples of such correspondence between Japan and the Song government, see von Verschuer, Across the Perilous Sea, p. 44

41 For an exchange of poetry between Sugawara no Michizane and a Parhae ambassador, as well as their diplomatic proceedings, see Borgen, Sugawara, pp. 227-54. The significance of poetry composition in Song-Liao diplomacy is also discussed in Tackett, The Origins of the Chinese Nation, pp. 44-45, 64 . monks but later used for private merchants, too. Daogu's trade mission to Japan was not so much as mentioned in the official records, yet his impressive poetic performance was duly noted years later by his admiring hosts. Daogu also won the favor of Emperor Ninmyō 仁明天皇 (810-850, r. 833-850) after he donated to the sovereign a compilation of poems from the famous Chinese poet Bo Juyi. This exchange likewise earned a promotion for the Japanese official who arranged it. ${ }^{42}$

Two decades later, in 858, a mixed group of merchants from China, Parhae, and Silla under the leadership of a Parhae merchant named Yi Yŏkhyo 李延孝 (d. 877) arrived at the Kōrokan along with their passenger, the Japanese monk Enchin 円珍 (814-891). Enchin, who later gained fame as one of the most prominent-and also disputed-patriarchs of the Tendai 天台 school, had joined this crew on his return journey from China. As the merchants waited out their final days before heading back to the continent, Enchin, who was waiting for permission to depart for the capital city of Heian, exchanged poems with this group in a festive and emotionally tinged send-off. These poems were recorded in a text that is now preserved as a government-designated National Treasure, titled Tōjin sōbetsushi narabini sekitoku 唐人送別詩种尺覑 (Chinese Farewell Poems and Correspondence). In the following poem, drawn from this text, the merchant Cai Fu 蔡輔 (d.u.) reassures Enchin that despite the controversial issue of the eight-year-old Emperor Seiwa 清和天皇 (850-881, r. 858-876) ascending the throne (and the beginning of what would become a prolonged Fujiwara regency), the capital would soon enough return to a state of stability. ${ }^{43}$

\section{唐帰入朝月騰光 \\ 新天時亮曙色霜 \\ 縦然浮雲暫遮却 \\ 須因還照莫苦 (傷力)}

Returning from China, the glistening moon rises on arrival at court,

The new day [i.e., the new emperor] shines with the dawn and frost's early light,

42 Nihon Montoku tennō jitsuroku, entries dated Ninju 仁壽 1 (851).9.26 and Ninju 2 (852).12.22. On the remarkably enthusiastic reception of Bo Juyi's poetry in Japan, see Smits, "Reading the New Ballads."

43 Saeki, Enchin, pp. 126-27. 
Even if the floating clouds conceal for but a moment,

In an instant, pain and distress are again cleared away. ${ }^{44}$

In addition to highlighting the literary ability of these merchants, such poems also reveal a surprising degree of insight into the political processes of their surrounding environments. As in later periods, sea merchants across East Asia at this time were clearly associating with important political figures or those who were connected to political centers, and the large variety of extant Japanese sources helps to shed light on this situation. This may be seen in the relationship between a Chinese man named Lu Zhiyuan 盧知遠 (d.u.), whom scholars generally presume was a merchant, and the Japanese scholar-official Miyoshi no Kiyotsura 三善清行 (847-919). On a trip to Japan in 901, Zhiyuan informed Kiyotsura about the eunuch Liu Jishu 劉季述's (?-901) attempted coup d'état in which thousands of people were allegedly killed in the vicinity of the Tang palace. ${ }^{45}$

Even more successful in his efforts to form connections with Japan's leaders was the merchant Li Yanhuan 李彦環 (d.u.), whom Emperor Uda 宇多天皇 (866931, r. 887-897) summoned to the capital for a meeting in $896 .{ }^{46}$ Although Uda later admitted that meeting Yanhuan without the cover of a curtain was one of his greatest regrets, the merchant does not seem to have committed any overly drastic transgressions, as he was allowed to return to Japan in $903 .{ }^{47}$ On this second occasion, Yanhuan was able to form a relationship with Sugawara no Michizane that allowed for the exchange of gifts. Michizane was by this time living out his final days in misery as an exiled governor of Dazaifu, the administrative center that oversaw traffic to and from

44 Tōjin sōbetsushi narabini sekitoku; for a Japanese transliteration and interpretation, see Saeki, Enchin, pp. 126-27.

45 Tokyō Daigaku Shiryō Hensanjo, Dai Nihon shiryō, vol. 1, entry dated Shōtai 昌泰 4 (901).3; Xin tang shu, vol. 19; and Somers, "The End of the T'ang," pp. 779-80.

46 Uda Tennō, Kanpyō goyuikai, pp. 104-106, 293-94; Nihon kiryaku, entry dated Kanpyō 寛平 8 (896).3.4; and Borgen, Sugawara, p. 213.

47 Robert Borgen provides the following translation from Uda's entry in the Kanpyō goyuikai: "When foreign guests must be received, greet them from behind a curtain; do not face upon them directly. I have already made an error with Li Huan [sic]." Ibid., p. 213. The type of curtain to be used in such circumstances is not indicated here. the continent. The following is a poem by Michizane, written as a "return gift" to Yanhuan, after the merchant gave the esteemed scholar-official a bamboo chair.

\section{彦環贈与竹縄床 \\ 甚好施来在草堂 \\ 応是商人留別去 \\ 自今遷客著相将 \\ 空心旧為遙踰海 \\ 落涙新如昔植湘 \\ 不費一銭得唐物 \\ 寄身偏愛惜風霜}

題竹床子。〈通事李彦環所送。〉

"Regarding the Bamboo Chair" (Given by the
interpreter Li Yanhuan)
Yanhuan gave a bamboo chair,
It is of good use inside the thatched hut,
And so there should be a gift for this parting
merchant,
Henceforth together with this exile,
Whose empty heart has long yearned to cross the
distant sea,
New teardrops are shed like the mottled bamboo
of old, ${ }^{48}$
Having not spent a coin to receive this Chinese
luxury,
It will be cherished through this moment of
hardship. ${ }^{49}$

This poem is significant in that it highlights the relationship formed between a Chinese merchant and a once-prominent Japanese scholar-official. Sugawara no Michizane, a staunch advocate of Confucian learning and Chinese institutions, is now known across Japan as the deity ( $k a m i$ 神) of learning, and is one of the most popular deities on the archipelago. That a man who consciously lived his life as a moral exemplar had no qualms with forming a close association with a merchant such as Li Yanhuan, demonstrates that merchants

48 This is a reference to the legend of Emperor Xun's 帝舜 consort Xiang Fei 湘妃 who drowned in the Xiang River 湘江. It is from this story that mottled bamboo (Ch. xiangfeizhu 湘竹 or 湘妃竹, Jp. shōhichiku) gets its name, as its spots are akin to teardrops that have sprayed onto the plants along the water of the Xiang River.

49 Kanke kōshū, poem 501. Part of my interpretation comes from the annotations of the editor of this work, Kawaguchi Hisao 川口 久雄. 
were not always judged primarily by their profession. Furthermore, we see here another merchant who, by Michizane's assessment, possessed an advanced degree of literary discernment. Needless to say, Michizane's "return gift" of a poem indicates that he owed no additional favors to Yanhuan, and one would think that had he deemed the matter inappropriate he would have denied the gift outright or simply left the matter undisclosed.

\section{The Merchant and the Official}

The above instances show that merchants from across East Asia frequently employed diplomatic protocol in the giving of gifts and the enactment of ceremony. As with diplomats, they also handled important correspondence to and from state leaders, and formed close relationships with officials from other states. However, despite the fact that examples of merchant families transitioning into officialdom and official families engaging in commerce can be found throughout a wide span of Chinese history, the perception of a barrier between both professions persists not only in the history of China, but also in the history of East Asia. This issue is perhaps best addressed by Joseph McDermott, who states that:

\section{The category "merchant" was neither a fixed nor exclusive category. It remained a derogatory term or category in some circles. But so long as trade was not a person's sole or principal activity, then it had little catch in a society where the most pres- tigious social status, "official," was itself available to all through examinations ... a man could thus withdraw from an official position, retain that legal status, while at the same time do work other than government service. ${ }^{50}$}

Despite this assessment being made in the context of China's late imperial history, I believe it is also valid to a large extent for the time frame of this essay. This is evident in that some examples of merchantofficial transitions are of retired officials engaging

50 McDermott, "Merchants in Late Imperial China." in commerce in the late Tang dynasty. ${ }^{51}$ Indeed, it is curious that although Tang merchants and their kin were supposedly barred by law from taking office, we see a wide range of examples in the Japanese sources of continental traders who clearly had the education necessary to compose poetry in the same capacity as a distinguished ambassador. ${ }^{52}$ That the merchant Cai Fu, noted above for his poem to Enchin in the Körokan, held a prefectural official's title should encourage us to further consider this point..$^{53}$

This brings us to the question of whether or not it was possible for those traders who traveled across East Asia to take up simultaneous roles as both a merchant and an official. Individual sources typically only distinguish between one or the other, though we do see some interesting results in the rare instances when Japanese sources can be compared with Chinese sources. This is particularly apparent in the case of Jiang Xun 蔣勳 (d.u.). Xun, who was actively trading in Japan from 935 to 952, is noted in Japanese history as one of the merchants who most frequently journeyed to the archipelago in the tenth century. ${ }^{54} \mathrm{He}$ also carried correspondence between the King of Wu-Yue and leading members of the Fujiwara regency (Japan's de facto rulers) on some of these journeys. ${ }^{55}$ However, an early-fourteenth-century funerary inscription of a Wuzhou 娿州 scholar named Jiang Jixiang 蔣吉相 (1274-1321) paints a different picture of Jiang Xun. Within this inscription is a genealogy that traces

51 Tackett, "Great Clansmen, Bureaucrats, and Local Magnates," pp. $112-13$.

52 In fact, the evidence presented thus far of merchants composing poetry in the ninth century predates earlier estimations of them having attained such skills by several centuries, that is, at the end of the Song dynasty. See Konishi, A History of Japanese Literature, p. 27. More recent arguments demonstrate that literacy was spreading beyond the shi stratum from the Northern Song onward. See Hymes, "Sung Society and Social Change." The evidence presented in this article may push back these estimations to the last century of the Tang dynasty, though it remains unclear if the dissemination of literacy was limited only to a certain portion of long-distance traders. As for Japan, some aristocratic women in the Heian period were also able to read Chinese texts, though the composition of Chinese-style poetry was, nevertheless, regarded as a preoccupation for male aristocrats and scholar-officials. See Smits, "The Way of the Literati," pp. 110-12.

53 Tōjin sōbetsushi narabini sekitoku; Yamazaki, Chūgoku godai kokka ron, p. 247.

54 Nihon kiryaku, entries dated Shōhei 5 (935).9; and Shōhei 6 (936).7.13; Honchō seiki, entry dated Tengyō 1 (938).8.23; and Takeuchi, Heian ibun, entry 4623, p. 3564.

55 Nihon kiryaku, entry dated Shōhei 6.7.13 
Jixiang's lineage back to a mid-ranking official in the Tang government's Ministry of Civil Appointment (Libu 吏部). As it turns out, this man was Jiang Xun's father. Of even greater interest is the proceeding description of Jiang Xun himself, which states that Xun "concurrently served Wu-Yue as Acting Minister of Works and as Vice Chancellor, [he] established [his] family in Dongyang [county] of Wu [prefecture]” 仕吳 越為其檢校司空兼御史大夫,始家于敂之東陽. 56

The case of Jiang Xun is intriguing because until now, scholars of this period have not considered such a close link between the "merchant" and "official" occupations in East Asian interstate exchange, especially not one that shows a ranking minister directly engaged in commerce. ${ }^{57}$ The reasons for this are perhaps best attributed to the nature of the sources themselves. The inscription of Jiang Jixiang from which we find information of Jiang Xun has survived the passage of time not because of the importance of these two figures, but because the man who wrote the inscription, Huang Jin 黃㳙 (1277-1357), was a prominent literatus in the Yuan 元 (1271-1368) government, as well as a leading figure in the Neo-Confucian movement of his time..$^{8}$ As such inscriptions were a valued part of his collected writings, they were deemed worthy for preservation and transmission by later generations. It is precisely

56 Quan Yuan wen, vol. 30, pp. 348-50. Scholars have previously referred to this man as Jiang Chengxun 蔣承勲 (with the variants of 勵 and 勛 used for the third character in his name), which is how his name appears in Japanese records. Here I use Jiang Xun 蔣勳, as this was the name that was recorded in Jiang Jixiang's funerary inscription. It should be noted that in the genealogy provided within, the first character of his son Jiang Chengying's 蔣承趴 given name is the same character that was used in Jiang Xun's given name in the Japanese records. I use the corresponding dates and origins attributed to this man in the funerary inscription and Japanese sources, the connection to the Wu-Yue court of the individual mentioned in both Chinese and Japanese sources, as well as the appearance of the character 承 in his given name in Japanese sources and in his son's given name in the Chinese funerary inscription, as evidence that these sources are discussing the same individual.

57 The closest example for comparison would be the local officials from western Japan who conducted trade missions in Korea during the Koryŏ 高麗 (918-1392) dynasty in the eleventh century, apparently without the backing of the court in Heian. See Yamauchi, Nara Heian ki no Nihon to Ajia, pp. 82-86.

58 Huang Jin belonged to a local group in Wuzhou that were later called the "Jinhua Confucians," of whom Peter Bol characterizes as "scholars who accepted Neo-Confucianism's universalism and theory of human nature, but rejected its exclusion of literary learning and statecraft." For a full discussion on Jinhua Confucians, see Bol, "Neo-Confucianism and Local Society," pp. 265-66. due to Huang Jin's fame as an intellectual that we know of Jiang Xun's past. Yet one notable characteristic of funerary inscriptions that authors such as Huang Jin composed, is an absence of discussion concerning commercial activity. This was in accordance with a cultural sensibility common among scholars in which ostentatious displays of wealth were generally associated with decadence or were deemed antithetical to the idealized image of an austere scholar. ${ }^{59}$ That is not to say that the men and women discussed in these inscriptions, or the authors themselves for that matter, were not well-off. In fact, quite often the opposite was true, as the expense of arranging funerals and inscription services necessitated access to a considerable amount of resources. Rather, Beverly Bossler, who has worked extensively on the Song funerary inscriptions of Wuzhou inhabitants, demonstrates that although the attainment of wealth was a means of establishing status in a local community, the commercial activity from which much of this wealth derived, was, nonetheless, an ill-suited topic for eulogies. Bossler states that "since trade was always considered somewhat less than respectable, biographical sources rarely document the involvement of families or individuals in the commercial activity we know was expanding rapidly during precisely this period." ${ }^{\circ 0}$ Since these inscriptions are the largest biographical source of information on Song individuals, the limitations of their subject matter pose a challenge in trying to understand the nature of the involvement of officials or of literati families in commerce at this time. Thus, details of Jiang Xun's background in the Chinese funerary inscription are limited only to a brief mention of his service in government, though we are fortunate to know from

59 Bossler, Powerful Relations, p. 18, and citation no. 87 on p. 285. For a discussion on funerary inscriptions, see pp. 9-24; and Ebrey, Yao, and Zhang, Chinese Funerary Biographies, pp. 3-18.

60 Bossler, Powerful Relations, citation no. 48 on p. 295; see also pp. 135-36, where Bossler notes the many wealthy families and the abundance of commodities in the Wuzhou area. She is certainly correct to suspect that many of these individuals were involved in commerce, as Japanese sources demonstrate that merchants of Wuzhou (not to be confused with Wu County [Wu xian 吳縣] in what is now the Suzhou area) were one of the most well-represented regional groups involved in the Japan trade during the Tang-Song transition, even despite the prefecture's landlocked mountainous topography. Three of these merchants and their Wuzhou origins are discussed in Yamazaki, Chūgoku godai kokka ron, pp. 189-94. 
Japanese sources of his engagement in commerce and in state to state correspondence.

We may also note that Jiang Xun was not the only prominent individual at this time to have had dual roles in both politics and trade. Such a circumstance also became apparent when the Min 閩 (909-945) general Liu Congxiao 留從效 (906-962) took control of southern Fujian in the mid-tenth century. In the wake of his victories, he sent military officials to conduct trade in the state of Later Zhou (Hou Zhou 後周, 951960). ${ }^{61}$ Although it is unclear whether these officials were of a learned background or were simply men who had fought their way to prominence alongside Liu Congxiao, we can still see an interplay of roles here that corresponds to Jiang Xun's time.

And roughly one century prior, we have an example of two Chinese brothers who were also involved in trade with Japan. The youngest brother, $\mathrm{Xu}$ Gongyou 徐公祐 (d.u.), made several trade voyages to Japan between 848 and 852. ${ }^{62}$ The older brother, Xu Gongzhi 徐公值 (d.u.), seems to have handled their affairs on the Chinese side, and addressed himself as an official from Wuzhou (that is, the "Honorary Commander of the Wuzhou Prefectural Office," Wuzhou yaqian sanjiang 㜈州衙前散將, essentially a low-tier office clerk). Although Xu Gongzhi's position was a sinecure post that may have held little to no actual responsibility, it nevertheless remains a marked connection between government officials and overseas trade. And as with merchants prior to and after their time, these brothers seem to have used the profits from their ventures to invest in land purchases. ${ }^{63}$

Perhaps just as noteworthy is the remarkably close proximity of the "merchant" and "official" designations in the region of Wuzhou. Although it was a landlocked mountainous area in modern Zhejiang Province, Wuzhou stands out in the sources for its involvement in overseas trade between China and Japan over the span of the Tang-Song transition. Not only do the activities of the Xu brothers and Jiang Xun highlight how officials engaged in overseas trade came from this area at different times throughout the Tang-Song transition, but

\footnotetext{
61 Song shi, volume 483; So, Prosperity, Region, and Institutions in Maritime China, pp. 33-34.

62 Kōya zappitsushū, entry dated Ninju 5 (852).5.22; Yamazaki, Chūgoku godai kokka ron, pp. 177-88; Saeki, Enchin, pp. 185-86; Watanabe, Heian jidai, p. 118.

63 Yamazaki, Chūgoku godai kokka ron, pp. 184, 187.
}

two of the merchants from the group who composed poetry on Enchin's return to Japan were from Wuzhou as well. ${ }^{64}$

On this note, we may turn to another example of a sea merchant whose name appears both in Japanese sources and in a Chinese funerary inscription. Adjacent to Wuzhou and located on the coast of modern Zhejiang Province was the neighboring prefecture of Taizhou 台州. In this area we see a rather interesting case in which wealth generated from overseas trade financed the education of members of the Song literati, and eventually contributed to their endeavor of lineage building. ${ }^{65}$ The Zhou family of Ninghai County (Ninghai xian 寧海縣) was involved in the lucrative Japan trade for at least two generations, starting in the late tenth century. Part of the key to their success was the arrangement of strategic marriages that supported their business interests, such as the marriage of the secondgeneration trader Zhou Wenyi 周文裔 (962-?) to the daughter of a Japanese courtier, or the marriage of their son Zhou Liangshi 周良史 (986-?) to the daughter of a prominent literati family from Mingzhou. It was in this latter case that we begin to see the transition of this group from a merchant family to a literati family, and it is Zhou Liangshi's name that appears in both Japanese and Chinese sources. For in 1021, Liangshi left his pregnant fourteen-year-old wife to captain a trade ship to Japan, and never again returned to his hometown. According to the funerary inscription of his wife, Lady Shi (Furen Shishi 夫人施氏, 1007-1080), she was faced with the arduous task of raising a son on her own with minimal support from her in-laws. Through her own initiative, she was able to educate herself, and then to pass on her knowledge as a means of providing an early education for her son, Zhou Bian 周弁 (10211093). After he showed great potential, members of the Zhou family financed her son's formal education in Hangzhou, and decades of sacrifice on the part of Zhou Bian and Lady Shi resulted in Zhou Bian passing the imperial examination to obtain a highly coveted jinshi

64 These two were Li Da 李達 (d.u.) and Zhan Jingquan 詹景全 (d.u.). See Tōjin sōbetsushi narabini sekitoku; and Yamazaki, Chūgoku godai kokka ron, p. 191.

65 The following draws mainly from Yamazaki, "Kaishō to sono tsuma." For discussion on lineage-building initiatives in the mid- and late imperial periods of Chinese history, see Ebrey, "The Early Stages in the Development of Descent Group Organization"; and Bol, Neo-Confucianism in History, pp. 29, 121, $144,240-46,258-60$. 
進士 degree-a considerable accomplishment which allowed him to take up a career as an official. ${ }^{66}$ From this point on, we can see that the transition to a literati family was complete, as many of Lady Shi and Zhou Bian's descendants went on to even higher positions of prominence in the Song government. The crux of Lady Shi's accomplishments occurred in 1112, when she received the ultimate recognition for a merchant's wife. In this year, Emperor Huizong (Song Huizong 宋徽宗, 1082-1135) publicly honored her achievements and posthumously conferred upon her the title "Lady of the State of Wei” (Weiguo Furen 魏國夫人).

Despite the remarkable story of Lady Shi, Zhou Bian, and the rest of the Zhou family, they were not alone in their attempts to transition from commercial success to attaining representation in state government at this time. Peter Bol has identified this trend as occurring primarily as wealthy families sought a means to protect their interests and gain the acceptance of local literati. As a result of these initiatives, the profits from merchant and landholding families were often invested in private academies, which in turn spurned some of the greatest intellectual movements of the day. ${ }^{67}$

Finally, if we turn toward Korean history, we may see that the close connection between merchant and official was not a phenomenon isolated to China and Japan. This is particularly evident from the early to mid-ninth century, when Korean merchants, sailors, and officials played a fundamental role in establishing the private trade networks that persisted across East Asia for many centuries. The man at the head of these efforts was the magnate Chang Pogo 張保泉 (790-841), though he relied on an infrastructure of thousands of Koreans that were spread throughout various states in East Asia. ${ }^{68}$ Pogo himself rose to prominence as a military official in the Tang armies, and may have been the private

66 It is possible that some extent of exaggeration framed the account of Lady Shi's moral qualities, as the story of a widow sacrificing much for the sake of her son's education was a common trope in the funerary inscriptions of this time. See Bossler, Powerful Relations, pp. 17-20. Also noteworthy here is that Zhou Bian spent part of his career as an official in Wuzhou, which when considered together with Lady Shi's literati family in Mingzhou, draws another connection between these locations and overseas trade between China and Japan.

67 Bol, Neo-Confucianism in History, pp. 36-37.

68 For more on Chang Pogo and his network, see Ennin, Ennin's Diary, pp. 100-104, 131; Reischauer, Ennin's Travels in T'ang China, pp. 287-94; Batten, Gateway to Japan, pp. 84-86, 112-13; and Kim "Frogs Looking Beyond a Pond," pp. 83-84. trader (or diplomat) called "Envoy Chang" (Jp. Chō Taishi 張大使), who arrived in Japan in $824 .{ }^{69}$ On his return to Korea he was made a maritime commissioner in charge of his own naval garrison, which became the headquarters of his trade network. A read through the journal of the Japanese monk Ennin 円仁 (794864), who gave a detailed account of his time spent in Korean diaspora communities in China, provides a clear depiction of the Korean officials who served in the Tang government but simultaneously lent support to Chang Pogo's activities. In an attempt to begin a trade relationship with the Japanese government, one such official constructed a boat to bring Ennin back to Japan, but his plan was discovered by a rival and he was forced to cease his illegal activities..$^{70}$ Pogo's commercial empire eventually came to a dramatic collapse in 841 when he was assassinated by a political adversary. Up to that point, he had amassed enough wealth and power that he was able to influence marriage politics in the Silla royal family, allowing for his daughter to become a wife of King Mŭnsŏng (Munsŏng wang 文聖王, ?-857). It would seem then that in the eyes of his enemies, Chang Pogo had come to embody the image of the over-powerful merchant of whom Legalist scholars appeared to abhor.

\section{A Different Attitude and Rhetoric}

Significant research has shed light on the suppressive laws and negative attitudes that some officials held toward domestic merchants in China during the Tang dynasty. ${ }^{71}$ Yet when we take a look at how officials across East Asia dealt with foreign merchants and the traders who exchanged luxury goods from the ninth to twelfth centuries, such attitudes appear to be the exception rather than the norm. A look at the language that was used and the way in which maritime merchants were treated at this time reveals much about their general predicaments and allows us a keen sense of the dynamic that existed between them and government officials. Detailed accountings of such interactions in the Japanese records are particularly helpful in this regard.

\footnotetext{
69 Ennin, Nittō guhō junrei gyōki, entry dated Kaishō 會昌 5 (845).9.22.

70 Ennin, Ennin's Diary, pp. 394-95.

71 Twitchett, "Merchants, Trade and Government"; Twitchett, "The T'ang Market System."
} 
To highlight this point, let us go back to the merchants of the Zhou family of Taizhou. During the decades that they were actively trading in Japan, Zhou Wenyi was able to take as his wife the daughter of a Japanese courtier; the earliest example of what became a common practice of Chinese merchants taking Japanese wives. Not only did Zhou Wenyi and his son Zhou Liangshi foster favorable relations with the Japanese government, they were also able to immigrate to Japan, and were likely among the first residents of the Chinese diaspora in Hakata. ${ }^{72}$ Even when Zhou Wenyi broke regulations meant to restrict the frequency of merchant arrivals (henceforth referred to as nenki 年紀 regulations), Japanese courtiers bent the rules to let him do business. ${ }^{73}$ The relationships that Wenyi and Liangshi fostered are noteworthy as they reached the highest levels of state-courtiers and royalty alike. This included leaders of the Fujiwara regent's house and Crown Prince Atsunaga (Atsunaga Shinnō 敦良親王), the future Emperor Gosuzaku 後朱雀天皇 (1009-1045, r. 1036-1045). ${ }^{74}$

Under the leadership of Fujiwara no Michinaga 藤原道長 (966-1028), the Japanese court in the early eleventh century was especially friendly to foreign merchants. Considered to be one of the most powerful courtiers in Japanese history, Michinaga made extensive use of foreign goods as gifts in his patronage network, and thus was keen to encourage foreign traders to make frequent visits to Japan. ${ }^{75}$ Also coinciding with Michinaga's time in power was a wave of immigration of Chinese merchants to Japan. ${ }^{76}$ There are indications that this led directly to the establishment of Hakata, the most important trade port in Japan for many centuries to come. Although we do see precedents of people from China and the Korean Peninsula immigrating to Japan

72 Yamazaki, "Kaishō to sono tsuma," p. 94.

73 Fujiwara no Michinaga, Midōkanpakuki, annotations, entries dated Chōwa 1 (1012).9.2; Chōwa 1.9.21; Chōwa 1.9.22. There is as yet no consensus among scholars as to the frequency in which merchants were permitted to visit Japan under such regulations, though most estimations are between once every two to once every three years. Watanabe Makoto argues that the regulations were intended to restrict arrivals to roughly once every ten to twelve years. See Watanabe, Heian jidai, pp. 206-44.

74 Yamazaki, "Kaishō to sono tsuma," p. 88.

75 For a description of these goods and how they were dispersed among the Japanese aristocracy, see Satō, "Kokufū to wa nani ka," pp. 284-86.

76 Honchō reisō, p. 606; Sattler, "Japan's Early Private Traders," pp. 42-50. since even before the beginning of its written history, Hakata is significant in that the settlement there became a permanent trading hub similar to other Chinese diasporas set up across Southeast Asia, and along the lines of the various foreign diasporas that were established throughout the Tang empire. ${ }^{77}$

As for the rhetoric that was used in the communication between foreign merchants and Japanese officials, here we may see a rather marked departure from most of the scholarship conducted on the social roles of both professions thus far. Bruce Batten has provided one example of this rhetoric in the instance of a merchant named Pan Huaiqing 潘懷清 (d.u.), who, similar to Zhou Wenyi, came to Japan in breach of nenki regulations in $1070 .{ }^{78}$ Huaiqing was nevertheless allowed to trade, in part due to the pretext he had given Japanese officials that he had come "yearning for the imperial virtue” (Ch. huanghua 皇化, Jp. oka). Batten has pointed out that an ideological component was part of the approval process for allowing foreign merchants to trade in Japan, noting that their arrival, provided that it was morally sound, reflected well on the state and its sovereign. ${ }^{79}$ This we can see is reflected in other sources of the period. For instance, two years prior to Huaiqing's arrival, the merchant Sun Zhong 孫忠 (d.u.) also arrived in breach of nenki regulations. He made his case by claiming to have come "yearning for the sovereign's virtue" (Ch. wanghua 王化, Jp. oka), and appears to have won some support from the Heian court, that is, until Dazaifu officials found some major discrepancies in his paperwork and he was thereupon denied permission to trade. ${ }^{80}$ Since Pan Huaiqing had traveled on this earlier voyage with Sun Zhong, it seems more than likely that he had noted the effectiveness of his partner's Confucian lexicon, and used it with greater success on his later trip. ${ }^{81}$

77 There is one example of a foreign merchant being given land and permission to reside in Japan long before the establishment of Hakata. See Nihon sandai jitsuroku, entries dated Gangyō 元慶 1 (877).6.9 and 1.8.22.

78 Batten, Gateway to Japan, pp. 113, 118-19. This case as well as the following cases in which similar rhetoric is used are also discussed in Yamauchi, Nara Heian ki no Nihon to Ajia, pp. 181-85.

79 Batten, Gateway to Japan, p. 113

80 Suisaki, Sochiki, entry dated Jiryaku 治暦 4 (1068).10.23. The characters 皇化 and 王化 are both read as ōka in Japanese and wohng $\backslash \mathrm{fa}$ - in Cantonese, so it is possible that they are interchangeable. The difference in meaning of the two graphs appears to be minimal, with the former referring to the influence of an emperor, and the latter referring to that of a sovereign.

81 As Confucian scholars traditionally conceived of tribes and states along China's borders as lacking reverence and understanding 
The precedents for the use of such rhetoric among merchants are apparent decades earlier during the time of Fujiwara no Michinaga, who in addition to the case of Zhou Wenyi, appears to have been involved in allowing three other merchants to trade in Japan in breach of the nenki regulations. ${ }^{82}$ The last of these instances provides some further insight on the ideological rationale that merchants and officials employed in their dealings. In 1027, the merchants Chen Wenyou 陳文祐 (d.u.) and Zhang Renchang 章仁䞟 (d.u.) came to Japan knowing full well that they were in violation of the trade regulations, but nevertheless had prepared an excuse that they hoped would vindicate their actions. Renchang's parents resided in Japan, and he himself was of mixed Chinese and Japanese lineage, with his father being a Chinese merchant, and his mother Japanese. Wenyou therefore made the case that he had come to reunite Renchang with his family, which was an issue of great urgency as Renchang's parents had become senile and required someone to look after them. Michinaga, who was most likely aware of this ruse but nevertheless appreciative of a proper pretext to trade, pointed out favorably that Renchang's mother was Japanese and suggested that they be allowed to do business. As for Wenyou, the court noted the feeling of virtue (Ch. dehua 德化, Jp. tokka) that he imparted throughout the process. Un fortunately for the pair, they were officially denied the right to trade, perhaps because the ailing Michinaga lacked the power to influence such matters in his final months. Yet the court decided that

\footnotetext{
of a true sovereign's virtue, in recording this type of discourse, Japanese courtiers were implying that the Japanese emperor upheld the ancient Chinese ideals of a sovereign, while demonstrating that the visiting merchants were civilized in their own right for being able to recognize his virtue and submitting themselves accordingly. Understandably, such hierarchal positioning, long since a mainstay of diplomatic exchange, was conducive toward establishing a successful business relationship. Yamauchi limits his interpretation of this rhetoric to a purely Japan-centric context, though I think that Japanese courtiers would have understood the universal nature of these values despite their use in political grandiloquence, or at least that such values were prevalent in societies with a literary culture. See Yamauchi, Nara Heian ki no Nihon to Ajia, pp. 183-88. For a discussion of the sixth century Liang dynasty scholar Cui Ling'en's 崔靈恩 (d.u.) views on foreign peoples and imperial virtue, see Shinkawa, "Bunmei (moji, kotoba, shisō) no idō: 'Ten' gainen o tegakari to shite."

82 Shōyūki, entries dated Kankō 寛弘 2 (1005).8.21; and Kankō 2.8.24; Shōyūki, entry dated Kannin 寛仁 4 (1020).9.14; Shōyūki, entries dated Manju 万寿 4 (1027).8.25; Manju 4.8.30; and Manju 4.9.14.
}

the traders were to be given preferable treatment and permission to reside in Japan for a limited amount of time, which in accordance with the parlance of the day likely equated to a partial allowance to trade. ${ }^{83}$

But just as trade could be legitimated on a moral basis, so too could it be rejected in such a manner. This was made clear in 842 when Yi Sojŏng 李少貞 (d.u.), a representative of the assassin of the Silla trade magnate Chang Pogo, made an aggressive appeal to the Japanese court to allow him to seize the cargo of a rival Silla merchant. The court denied Sojöng on the premise that he had once served under Chang Pogo, and thus had proven himself disloyal and untrustworthy. ${ }^{84}$

In contrast to their views on relatively small-time domestic merchants, influential figures across East Asia commonly held positive attitudes toward the foreign merchants who possessed great quantities of prestige goods as well as generous attitudes toward gift-giving. These traders were not always welcome, especially when they breached regulations at inopportune times, or when economic hardship caused an embarrassing strain on the ability to purchase such goods. But as we have seen, in many cases the violation of rules could be condoned, and this was often done with the reasoning that it would be improper not to shelter the traders and their crews in the cold winter weather, or that their moral qualities legitimized such transactions.

\section{Conclusion}

The place of the foreign merchant in East Asian history is quite different from the negative image of the merchant that has emerged from the readings of Chinese laws and court histories. By and large, this may be attributed to the influence that the most successful merchants were able to exercise due to their acquisition and dissemination of wealth. For even under hostile governments or rigidly structured economies, these merchants were still often able to form alliances with government officials and to adapt to the challenges of their day.

83 Shōyūki, entries dated Manju 4 (1027).8.25; Manju 4.8.30; and Manju 4.9.14.

84 Shoku Nihon kōki, entry dated Jōwa 承和 11 (842).1.10; Watanabe, Heian jidai, pp. 17-25. For the argument that the Japanese court had not subsequently denied trading rights to all Silla traders, but rather to those with factional ties to the Silla government, see Watanabe, Heian jidai, pp. 16-37. 
Such an advent did not begin in the periods of deregulation that have come to characterize the late Tang and Song dynasties. Just as successful merchant families could transition to the ranks of officialdom at certain times during the Song dynasty, the same may be said for the Han dynasty as well. In both early and mid-imperial China the place of the merchant was suppressed by laws that were sometimes followed and sometimes ignored, depending on the sociopolitical conditions of the time. All of this suggests that there was a greater degree of continuity in the social maneuverability of merchants in Chinese history than has been previously acknowledged. Rather than conceiving a teleological improvement of the merchant's position in society over a long span of history, it may be more accurate to consider that their position changed periodically for better or worse based on the government policies of their day. And despite the heated rhetoric at certain times, there was usually nothing personal in the policies that were being introduced at the expense of merchants. For when government monopolies were instituted in China, merchants were recruited to oversee them. Rather, we see at various points in East Asian history, just as in the history of any society, an underlying theme of contention for wealth and power as a root cause for division.

And just as we can see that the place of the merchant and the place of the official could coincide, so too can we say the same for the conception of private trade and diplomacy. Following the decline of official diplomacy in East Asia in the ninth century, merchants and monks could take on the roles formerly attributed to state diplomats, and were allowed the privilege of staying at the government-sponsored lodgings that were constructed for the purpose of tributary exchange. Rather than assume that private trade and diplomacy were always easily distinguishable, we should consider that at certain times both designations were close enough to overlap and yet remain a matter of interpretation between the parties involved. This is evident in the instances when Japanese traders sold weapons to the state of Liao 遼 in 1091 and 1092. In the Liao shi 遼史 (History of Liao, completed in 1344), these events were recorded as "tribute," though as the export of weapons was illegal in Japan, the authorities there considered it to be nothing more than illicit trade and punished those who were involved. ${ }^{85}$ In the case of Jiang Xun of Wu-Yue, this idea begs some pertinent questions. In particular, when a state official arrives at a foreign country to trade - with indications that he was acting at the behest of his government no less-one has to wonder why he should not be called a diplomat. As historians have maintained that Japan was not engaged in official diplomacy at this time or in the following centuries, such an assertion could potentially open up a new can of worms. Though one can only speculate on the particularities of Jiang Xun's voyages, I am inclined to think that he was sent to Japan as an official representing the $\mathrm{Wu}$-Yue court, and that Japanese officials recorded him as a merchant so as to give sanction to his visits under a framework that permitted trade with private individuals. Whether or not this was the case, Jiang Xun's circumstances encourage a reconsideration of the precise nature of Japan's engagement with its neighbors at this time; one in which the notion of diplomatic isolation may prove inadequate in conceptualizing what increasingly appears to be a nuanced yet pragmatic system of interstate relationships. ${ }^{86}$

Finally, quite often the negative perception of merchants in East Asian history is attributed to a traditional "Confucian" view. This article has hopefully demonstrated that this is not an altogether accurate assessment. For as we have seen, trade in East Asia, as with the tributary protocol of earlier centuries, shared a common set of what we may call Confucian traditions. Yet we should also hesitate to assume that Confucians by and large held favorable views of merchants, as there clearly exists a potential for conflict between the goal of amassing wealth and the Confucian disdain of greedy behavior. $^{87}$

85 Liao shi, entries dated Da'an 大安 7 (1091).9.14; and Da'an 8 (1092).9.27; von Verschuer, Across the Perilous Sea, p. 45. A similar instance of "Japanese tribute" is reported in the Liao shi for the year 925, but is not mentioned in Japanese sources. See Liao shi, entry dated Tianzan 天賛 4 (925).10.21.

86 For arguments against the notion of Japan as a country in isolation at this time, see Batten, To the Ends of Japan; and Yamauchi, Nara Heian ki no Nihon to Ajia, pp. 167-89. Batten nevertheless takes a position similar to that of a more recent generation of Japanese scholars: that Japan was in a state of diplomatic isolation (rather than general isolation), whereas Yamauchi highlights the rhetoric of tributary diplomacy in the exchange between sea merchants and Japanese officials, but emphasizes the role of these merchants as non-state actors who at times functioned as intermediaries in state-to-state relations.

87 It should also be noted that the members of the Ban family, whose Han shu was highly critical of merchants, were staunch Confucians themselves. 
Despite the many scholar-officials who disliked those who profited from the labor of others, merchants appear to have been marginalized for the most part only at times when they were deemed to be a direct political threat (such as Chang Pogo) or an economic rival to their respective governments (such as those who amassed fortunes in China by circulating coins, iron, or salt). In the case of maritime traders, we have seen that it is important to separate rhetoric from convention, as their values were often aligned with those of different occupations, be they monk or official. Granted such links were for the mutual gain of each of these parties-usually defined in economic terms-though the efforts of merchants to associate and integrate with these groups would have been facilitated by an ability to conform to their respective social norms and demonstrate a similarly defined background, particularly in regard to education, literary ability, and moral conduct.

\section{Reference List}

\section{- Abbreviations Used}

KST Shintei zōho kokushi taikei 新訂増補国史大系. 66 vols. Yoshikawa Kōbunkan, 1929-1964.

NKBT Nihon koten bungaku taikei 日本古典文学大系. 102 vols. Iwanami Shoten, 1957-1967.

\section{- Primary and Secondary Sources}

Batten, Bruce L. Gateway to Japan: Hakata in War and Peace, 500-1300. University of Hawai'i Press, 2006.

Batten, Bruce L. To the Ends of Japan: Premodern Frontiers, Boundaries, and Interactions. University of Hawai'i Press, 2003.

Bol, Peter K. "Neo-Confucianism and Local Society, Twelfth to Sixteenth Century: A Case Study." In The Song-YuanMing Transition in Chinese History, ed. Paul Jakov Smith and Richard von Glahn, pp. 241-83. Harvard University Asia Center, 2003.

Bol, Peter K. Neo-Confucianism in History. Harvard University Asia Center, 2008.

Bol, Peter K. "This Culture of Ours": Intellectual Transitions in T'ang and Sung China. Stanford University Press, 1992.

Borgen, Robert. Sugawara no Michizane and the Early Heian Court. University of Hawai'i Press, 1994.
Bossler, Beverly. Powerful Relations: Kinship, Status, \& the State in Sung China (960-1279). Council on East Asian Studies, Harvard University, 1998.

Ch'en, Ch'i-yün. "Confucian, Legalist, and Taoist Thought in Later Han." In vol. 1 of The Cambridge History of China, ed. Denis Twitchett and John K. Fairbank, pp. 766-807. Cambridge University Press, 2008.

Ebrey, Patricia B. "The Early Stages in the Development of Descent Group Organization.” In Kinship Organization in Late Imperial China, 1000-1940, ed. Patricia Buckley Ebrey and James L. Watson, pp. 16-61. University of California Press, 1986.

Ebrey, Patricia B., Ping Yao, and Cong Ellen Zhang, eds. Chinese Funerary Biographies: An Anthology of Remembered Lives. University of Washington Press, 2019.

Ennin. Ennin's Diary: The Record of a Pilgrimage to China in Search of the Law. Trans. Edwin O. Reischauer. New York: Ronald Press, 1955.

Ennin 円仁, comp. Nittō guhō junrei gyōki 入唐求法巡礼 行記. 4 vols. Heibonsha, 1970.

Fairbank, John K. Trade and Diplomacy on the China Coast: The Opening of the Treaty Ports, 1842-1854. Harvard University Press, 1953.

Farris, William W. "Trade, Money, and Merchants in Nara Japan.” Monumenta Nipponica 53:3 (1998), pp. 303-34.

Fujiwara no Michinaga 藤原道長. Midōkanpakuki 御堂関 白記. 3 vols. Dai Nihon kokiroku 大日本古記録. Iwanami Shoten, 1949.

Fusō ryakki 扶桑略記. Comp. Kōen 皇円. 30 vols. Yoshikawa Kōbunkan, 1965.

Hansen, Valerie. The Silk Road: A New History. Oxford University Press, 2012.

Hartman, Charles. "Sung Government and Politics." In vol. 5, part 2 of The Cambridge History of China, ed. John W. Chaffee and Denis Twitchett, pp. 19-138. Cambridge University Press, 2015.

Honchō reisō 本朝麗藻. Comp. Takashina no Moriyoshi 高階積善. Vol. 127. Gunsho ruijū 群書類従. Yagi Shoten, 2014.

Honchō seiki 本朝世紀. Comp. Shinzei 信西. 20 vols. Yoshikawa Kōbunkan, 1933.

Hymes, Robert. "Sung Society and Social Change." In vol. 5, part 2 of The Cambridge History of China, ed. John W. Chaffee and Denis Twitchett, pp. 526-664. Cambridge University Press, 2015.

Hyun, Jeongwon. "Gift Exchange among States in East Asia During the Eleventh Century." PhD dissertation, University of Washington, 2013. 
Kanke bunsō 菅家文草. Comp. Sugawara no Michizane 菅原道真. NKBT 72.

Kanke kōshū 菅家後集. Comp. Sugawara no Michizane. NKBT 72.

Kim, Sujung. "Frogs Looking Beyond a Pond: Shinra Myojin in the 'East Asian Mediterranean' Network." In The Sea and the Sacred in Japan: Aspects of Maritime Religion, ed. Fabio Rambelli, pp. 79-88. New York: Bloomsbury Academic, 2018.

Konishi, Jin'ichi. A History of Japanese Literature: Volume One, the Archaic and Ancient Ages. Princeton University Press, 1984.

Kornicki, Peter F. Languages, Scripts, and Chinese Texts in East Asia. Oxford University Press, 2018.

Kōya zappitsushū 高野雑筆集. Vol. 319. Gunsho ruijū. Yagi Shoten, 2014.

Levine, Ari D. "Che-tsung's Reign (1085-1100) and the Age of Faction." In vol. 5, part 1 of The Cambridge History of China, ed. Denis Twitchett and Paul J. Smith, pp. 484-555. Cambridge University Press, 2009.

Levine, Ari D. “The Reigns of Hui-tsung (1100-1126) and Ch'in-tsung (1126-1127) and the Fall of the Northern Sung." In vol. 5, part 1 of The Cambridge History of China, ed. Denis Twitchett and Paul J. Smith, pp. 556-643. Cambridge University Press, 2009.

Lewis, Mark E. The Early Chinese Empires: Qin and Han. Harvard University Press, 2010.

Lewis, Mark E. "Warring States: Political History." In The Cambridge History of Ancient China: From the Origins of Civilization to 221 B.C., ed. Michael Loewe and Edward L. Shaughnessy, pp. 587-650. Cambridge University Press, 1999.

Liao shi 遼史. Comp. Toqto’a. 5 vols. Hong Kong: Chung Hwa Book Co., 2003.

Liu, Guanglin. "Wrestling for Power: The State and Economy in Later Imperial China, 1000-1770." PhD dissertation, Harvard University, 2005.

Liu, Shufen. "The Southern Economy." In vol. 2 of The Cambridge History of China, ed. Albert E. Dien and Keith N. Knapp, pp. 330-54. Cambridge University Press, 2019.

McDermott, Joseph P. "Merchants and Trade Networks in Late Imperial China." In vol. 1 of The Cambridge Economic History of China, ed. Richard von Glahn. Cambridge University Press (forthcoming).

McDermott, Joseph P. "Merchants in Late Imperial China: Obstacles and Solutions." In Merchant Culture, ed. Catia Atunes and Francisco Betancourt. Leiden: Brill (forthcoming).
McDermott, Joseph P., and Shiba Yoshinobu. "Economic Change in China, 960-1279." In vol. 5, part 2 of The Cambridge History of China, ed. John W. Chaffee and Denis Twitchett, pp. 321-436. Cambridge University Press, 2015.

Nakamura, Tsubasa. “The Maritime East Asian Network in the Song-Yuan Period." Paper presented at "International Interdisciplinary Conference on Middle Period China, 800-1400," Harvard University, 5-7 June 2014.

Nihon kiryaku 日本紀略. Vol. 5. Kokushi taikei 國史大系. Keizai Zasshisha, 1906.

Nihon Montoku tennō jitsuroku 日本文徳天皇実録. Comp. Fujiwara no Mototsune 藤原基経. KST 3 .

Nihon sandai jitsuroku 日本三代実録. Comp. Fujiwara no Tokihira 藤原時平. KST 4 .

Nylan, Michael. “Assets Accumulating: Sima Qian’s Perspective on Moneymaking, Virtue, and History." In Views from Within, Views from Beyond: Approaches to the Shiji as an Early Work of Historiography, ed. Hans van Ess, Olga Lomová, and Dorothee Schaab-Hanke, pp. 131-67. Wiesbaden: Harrassowitz Verlag, 2015.

Quan Yuan wen 全元文. Comp. Li Xiusheng 李修生. 60 vols. Nanjing: Fenghuang Chubanshe, 2004.

Reischauer, Edwin O. Ennin's Travels in T'ang China. New York: Ronald Press, 1955.

Rossabi, Morris, ed. China Among Equals: The Middle Kingdom and its Neighbors, 1oth-14th Centuries. University of California Press, 1983.

Saeki Arikiyo 佐伯有清. Enchin 円珍. Yoshikawa Kōbunkan, 1990.

Satō Masatoshi 佐藤全敏. “Kokufū to wa nani ka” 国風とは 何か. In Nihon kodai kōryūshi nyūmon 日本古代交流史 入門, ed. Suzuki Yasutami 鈴木靖民, Kaneko Shūichi 金子修一, Tanaka Fumio 田中史生, and Ri Sonshi 李成市, pp. 282-320. Bensei Shuppan, 2017.

Sattler, Gregory. “Japan's Early Private Traders: The Lives and Activities of Overseas Merchants." MA thesis, Kyushu University, 2019.

Schafer, Edward H. The Golden Peaches of Samarkand. University of California Press, 1963.

Schottenhammer, Angela. "China's Emergence as a Maritime Power." In vol. 5, part 2 of The Cambridge History of China, ed. John W. Chaffee and Denis Twitchett, pp. 437-525. Cambridge University Press, 2015.

Shiba, Yoshinobu. "Sung Foreign Trade: Its Scope and Organization.” In Rossabi, pp. 89-115.

Shinkawa Tokio 新川登亀男. “Bunmei (moji, kotoba, shisō) no idō: ‘Ten' gainen o tegakari to shite” 文明 (文字. ことば・思想)の移動:「天」概念を手掛りとして. In Nihon 
kodai kōryūshi nyūmon, ed. Suzuki Yasutami, Kaneko Shūichi, Tanaka Fumio, and Ri Sonshi, pp. 389-409.

Bensei Shuppan, 2017.

Shoku Nihon kōki 続日本後紀. Comp. Fujiwara no Yoshifusa 藤原良房. KST 3 .

Shōyūki 小右記. Fujiwara no Sanesuke 藤原実資. Ed. Tōkyō Daigaku Shiryō Hensanjo. Vol. 4. Dai Nihon kokiroku. Iwanami Shoten, 1967.

Smith, Paul J. "Shen-tsung's Reign and the New Policies of Wang An-shih, 1067-1085." In vol. 5, part 1, of The Cambridge History of China, ed. Denis Twitchett and Paul J. Smith, pp. 347-483. Cambridge University Press, 2009.

Smits, Ivo. "Reading the New Ballads: Late Heian Kanshi Poets and Bo Juyi." In Wasser-Spuren: Festschrift für Wolfram Naumann, ed. Stanca Scholz-Cionca, pp. 169-84. Wiesbaden: Otto Harrassowitz, 1997.

Smits, Ivo. "The Way of the Literati: Chinese Learning and Literary Practice in Mid-Heian Japan." In Heian Japan: Centers and Peripheries, ed. Mikael S. Adolphson, Edward Kamens, and Stacie Matsumoto, pp. 105-28. University of Hawai'i Press, 2007.

So, Billy K. L. Prosperity, Region, and Institutions in Maritime China: The South Fukien Pattern, 946-1368. Harvard University Asia Center, 2000.

Somers, Robert M. “The End of the T'ang.” In vol. 3, part 1 of The Cambridge History of China, ed. Denis Twitchett, pp. 682-789. Cambridge University Press, 2008.

Song shi 宋史. Comp. Toqto’a. 496 vols. Zhonghua Shuju, 1977.

Song Xi 宋晞. Song shi yanjiu luncong 宋史研究論叢. Taipei: Zhongguo Wenhua Yanjiusuo, 1962.

Sterckx, Roel. "Ideologies of the Peasant and Merchant in Warring States China." In Ideology of Power and Power of Ideology in Early China, ed. Yuri Pines, Paul R. Goldin, and Martin Kern, pp. 211-48. Leiden: Brill, 2015.

Suisaki, Sochiki 水左記·帥記. Comp. Minamoto no Tsunenobu 源経信. Vol. 11. Shiryō tsūran 史料通覧. Nihon Shiseki Hozon Kai, 1916.

Swann, Nancy L. Food and Money in Ancient China: The Earliest Economic History of China to AD 25; Han Shu 24 with Related Texts, Han Shu 91 and Shih-Chi 129. Princeton University Press, 1950.

Tackett, Nicolas. “Great Clansmen, Bureaucrats, and Local Magnates: The Structure and Circulation of the Elite in Late-Tang China." Asia Major, Third Series, 21:2 (2008), pp. 101-52.
Tackett, Nicolas. The Origins of the Chinese Nation: Song China and the Forging of an East Asian World Order. Cambridge University Press, 2017.

Takeuchi Rizō 竹内理三, comp. Heian ibun 平安遺文. Tōkyōdō, 1965.

Tōjin sōbetsushi narabini sekitoku 唐人送別詩㷏尺覑. Senshu Daigaku kodai Higashi Ajia sekaishi nenpyō 専修 大学古代東アジア世界史年表. http://www.senshu-u. ac.jp/ off1024/nenpyoushiryou/tojinsoubetu/ tojinsoubetu.htm.

Tokyō Daigaku Shiryō Hensanjo 東京大学史料編纂所, comp. Dai Nihon shiryō 大日本史料. 343 vols. Tōkyō Daigaku Shuppankai, 1968.

Twitchett, Denis. "A Confucian's View of the Taxation of Commerce: Ts'ui Jung's Memorial of 703." Bulletin of the School of Oriental and African Studies 26:2 (1973), pp. 429-45.

Twitchett, Denis. "Merchants, Trade and Government in Late T'ang.” Asia Major, New Series, 14:1 (1968), pp. 63-95.

Twitchett, Denis. “The T’ang Market System.” Asia Major, New Series, 12:2 (1966), pp. 202-48.

Uda Tennō 宇多天皇, comp. Kanpyō goyuikai 寛平御遺誡. Vol. 475. Gunsho ruijū. Yagi Shoten, 2014.

von Glahn, Richard. Fountain of Fortune: Money and Monetary Policy in China, 1000-1700. University of California Press, 1996.

von Glahn, Richard. The Economic History of China: From Antiquity to the Nineteenth Century. Cambridge University Press, 2016.

von Glahn, Richard. "The Ningbo-Hakata Merchant Network and the Reorientation of East Asian Maritime Trade, 1150-1350." HJAS 74:2 (2014), pp. 249-79.

von Verschuer, Charlotte. Across the Perilous Sea. Cornell East Asia Series, 2006.

Wang, Zhenping. Ambassadors from the Islands of Immortals: China-Japan Relations in the Han-Tang Period. University of Hawai'i Press, 2005.

Wang, Zhenping. Tang China in Multi-Polar Asia: A History of Diplomacy and War. University of Hawai'i Press, 2013.

Watanabe Makoto 渡邊誠. Heian jidai bōeki kanri seidoshi no kenkyū 平安時代貿易管理制度史の研究. Shibunkaku Shuppan, 2012.

Worthy, Edmund H. "Diplomacy for Survival: Domestic and Foreign Relations of Wu Yüeh, 907-978.” In Rossabi, pp. 17-44.

Xin tang shu 新唐書. Comp. Ouyang Xiu 歐陽修 and Song Qi 宋剠. 20 vols. Hong Kong: Chung Hwa Book Co., 1975. 
Xiong, Victor C. “The Northern Economy.” In vol. 2 of The Cambridge History of China, ed. Albert E. Dien and Keith N. Knapp, pp. 309-29. Cambridge University Press, 2019. Yamauchi Shinji 山内晋次. Nara Heian ki no Nihon to Ajia 奈良平安期の日本とアジア. Yoshikawa Kōbunkan, 2003.

Yamazaki Satoshi 山崎覚士. Chūgoku godai kokka ron 中国 五代国家論. Bukkyō Daigaku, 2010.

Yamazaki Satoshi. "Kaishō to sono tsuma: Jūichi seiki Chūgoku no enkai chiiki to Higashi Ajia kaiiki kōeki” 海商とその妻: 十一世紀中国の沿海地域と東アジア海 域交易. Rekishi gakubu ronshū 歴史学部論集 1 (2011), pp. 87-99.

Yang, Lien-sheng. "Government Control of Urban Merchant in Traditional China." The Tsing Hua Journal of Chinese Studies, New Series, 8:1-2 (1970), pp. 186-209.

Yü Ying-shih. "Han Foreign Relations." In vol. 1 of The Cambridge History of China, ed. Denis Twitchett and John K. Fairbank, pp. 377-462. Cambridge University Press, 2008.

Zhu Ruixi 朱瑞熙. “Song dai shangren de shehui diwei ji qi lishi zuoyong” 宋代商人的社会地位及其历史作用. Lishi yanjiu 历史研究 2 (1986), pp. 127-43. 